\title{
Teaching and Researching Entrepreneurship: The Small Business I nstitute 2016
}

STEVE CRAMER

University of North Carolina at Greensboro, United States

\section{Small Business I nstitute Annual Academic Conference 2016 \\ New Orleans, LA \\ Feb. 10-13, 2016 \\ http://www.small lbusinessinstitute. biz/}

\section{About the Small Business I nstitute}

The Small Business Institute (SBI) held its 40th anniversary conference in New Orleans in February. According to its constitution, the mission of SBI "is to be the premier provider of professional development for those engaged in experiential student team consulting and related entrepreneurship education, research and activities." In addition to hosting conferences, SBI publishes two open-access journals: The Small Business Institute Journal and the Journal of Small Business Strategy. These are tremendous resources that academic business librarians may use when helping students and community members in their research in this space.

\section{Nature of the SBI Conference}

The annual conference consists of board meetings, keynote speakers, the presentation of research papers, workshops on teaching strategies, future research topics, and social opportunities for networking and mentoring. Awards are presented at each conference for best practices, student project of the year, best papers, service in mentoring, and professional achievement.
Around 150 people attended the conference this year. Most of the attendees were professors of small business and entrepreneurship from the United States. Also in attendance, were a Polish professor, a $\mathrm{PhD}$ student, and three academic business librarians, Diane Campbell (Rider University), Mary Scanlon (Wake Forest University), and the author.

The nature of concurrent sessions was different from most library conferences. Each session was 90 minutes long. A session could be labeled a workshop and include only one or two topics, but most of the 90 -minute sessions included three or four presentations. Tracks included, among others:

- Best Practices

- Small Business

- Global Entrepreneurship

- Family Business

- Experiential Learning

SBI publishes open-access proceedings of each conference, available from the organization's website:

www.smallbusinessinstitute.biz

\section{Small Business in New Orleans}

The conference's opening luncheon on Thursday featured Ben Johnson, President and CEO New Orleans Chamber of Commerce. Johnson discussed the efforts to support the small business community in the city after

Steve Cramer is the business librarian at the University of North Carolina Greensboro, smoramer@unc.edu. 
Katrina and to encourage entrepreneurs to take root there. He noted the large number of entrepreneurs who have moved into New Orleans after the disaster to start businesses but lamented the small number of native entrepreneurs in the majority-minority city. Johnson acknowledged that the billions of dollars of federal government spending on infrastructure since Katrina have boosted the local economy.

\section{Best Practices in Community Engagement}

Andrew Holt, Christine Kuglin, and Michael Montoya (Metropolitan State University of Denver) discussed "Developing and Embedding Student Skills for the Management of a Small Tax Firm: Evidence from a University-Level Experiential Learning Program." In this program, accounting students helped members of the public complete tax returns. The students had only finished one year of accounting courses, and thus found some of the more complex returns to be challenging. However, such work fulfills AICPA services standards and provided excellent real-world experience for the students.

Ron Cook, Lee Zane, and Diane Campbell (Rider University) presented "How to Create High Impact Community Outreach through a Veteran Entrepreneurship Training Program." Their entrepreneurship program recruited a local bank in New Jersey as a funding partner to provide entrepreneurship training and support for veterans who have business ideas. The campus Veteran Affairs Office made recruitment of local veterans fairly easy. The veterans most appreciated the mentoring program and student-faculty interaction. Campbell discussed how the program was designed around the preferences of militarystyle training and adult learners: a lot of structure, utilization of life experiences, and efficiency in instruction. In fact, one of the big challenges the veterans had been dealing with was the general lack of structure in an entrepreneurial lifestyle. Campbell provided research instruction for the veterans and tried to connect them with library resources across the state. Zane connected this program to AACSB's emphasis on community engagement.

\section{Research I deas in Small Business}

Matthew Sonfield (Hofstra University) presented preliminary research in "New and Ongoing Retail Venture Strategy: Utilizing Regional Consumer Expenditure.” He proposed comparing U.S. Bureau of Labor Statistics Consumer Expenditure Survey regional and city data to the consumer interest data provided by Google Trends. Sonfield believes this comparison could help entrepreneurs make decisions on new locations. He invited feedback on the strengths and weaknesses of this research strategy. One of the librarians in attendance offered suggestions on the availability of expenditure data more detailed by level of geography and on the availability of psychographic data.

Joe Felan (University of Arkansas Little Rock) introduced his research idea "Are There More or Fewer Opportunities for SMEs in the Supply Chain." He discussed using U.S. Census County Business Patterns data to measure supply chain trends in Arkansas by focusing on related NAICS sectors such as NAICS 48-49, the "Transportation and Warehousing" sector. There was a lively discussion about the nature of the data, and the possible conclusions. 
Ticker: The Academic Business Librarianship Review, 1:3 (2016)

\section{Experiential Learning}

Joseph Bell (University of Arkansas at Little Rock) presented "Academic Case Study Publications at Your Finger Tips," He discussed the value of case studies as a teaching method but lamented the lack of case studies on entrepreneurial ventures. He led a discussion with the audience on alternative sources of cases, which included several new case study textbooks published by members of the audience.

The three librarians in attendance, Campbell, Scanlon, and Cramer, presented on "Teaching Entrepreneurship Research Skills to Students: Best Practices from Three Entrepreneurship Librarians.” They provided recommendations to the professors on incorporating secondary research needs and requirements into their research assignments, and on how the professors could collaborate with their local business librarians. Attendees asked the librarians questions about database prices, how libraries are measuring and evaluating usage of subscription databases, and if databases can be legally used to support existing business ventures. The librarians described how cost per use of databases is widely used by libraries, a policy that can put expensive business databases at a disadvantage compared to generally cheaper humanities and social science databases. Therefore, the librarians continued, it is integral for both business professors and librarians to encourage students to use business databases. The librarians also discussed the possible grey area concerning use of subscription databases to support existing businesses, asserting that library database use is appropriate in cases where students are consulting for a business or entrepreneur as part of a class project. Such community engagement in support of economic development, is increasingly common in business schools, according to the presenters.

The professors also asked if they should encourage their students to ask for research consultations with librarians and if all librarians offer synchronous chat reference services. The librarian presenters confirmed that providing student research consultations is a major and welcome role of business librarians. However, the librarians expressed a difference of opinion regarding the value of providing a "business librarian chat service" separate from the general chat service provided by a library's reference desk. One librarian asserted that business research projects are often too complicated to work through over a chat interface. Another librarian whose business school offers several distance education programs believes there is value in providing a business librarian chat service, at least for more introductory business research needs. 